University of Pennsylvania Carey Law School

Penn Carey Law: Legal Scholarship Repository

Faculty Scholarship at Penn Carey Law

2020

\title{
Losing the Right to Assert You've Been Wronged: A Study in Conceptual Chaos?
}

Kimberly Kessler Ferzan

University of Pennsylvania Carey Law School

Follow this and additional works at: https://scholarship.law.upenn.edu/faculty_scholarship

Part of the Criminal Law Commons, Intellectual Property Law Commons, Law and Philosophy Commons, Public Law and Legal Theory Commons, and the Torts Commons

\section{Repository Citation}

Ferzan, Kimberly Kessler, "Losing the Right to Assert You've Been Wronged: A Study in Conceptual Chaos?" (2020). Faculty Scholarship at Penn Carey Law. 2322.

https://scholarship.law.upenn.edu/faculty_scholarship/2322

This Book Chapter is brought to you for free and open access by Penn Carey Law: Legal Scholarship Repository. It has been accepted for inclusion in Faculty Scholarship at Penn Carey Law by an authorized administrator of Penn Carey Law: Legal Scholarship Repository. For more information, please contact PennlawIR@law.upenn.edu. 
Penultimate draft. Not for citation.

Losing the Right to Assert You've Been Wronged: A Study in Conceptual Chaos?

Kimberly Kessler Ferzan*

There's this burrito joint that's not too far from here, and they make a pretty good burrito.

It's also a very inexpensive burrito, as their

cadillac [sic] entre [sic] is the most expensive at $\$ 4.10$.

And for that, you get a whole lot of food.

A burrito as big as your head, even.

\section{--Blake Field ${ }^{1}$}

It is hard to believe that this "poem" was the subject of a copyright dispute. ${ }^{2}$ Or that statutory damages for copying it would have been $\$ 50,000$. However, Blake Field's claim that Google violated his copyright for this and fifty other similar poems could have yielded $\$ 2,550,000$ in damages. ${ }^{3}$ Field lost, though not on the rather obvious grounds of lack of talent.

Field wrote fifty-one poems, registered copyrights, and then put them on his personal website. Google's automated program, Googlebot, surveys the web, finds websites, and copies them into a repository (a "cache"). Field, knowing how Google works, both included a program welcoming Google's Googlebot and intentionally refrained from including a metatag that would have told Google not to copy his work. Google cached Field's poems, and then, a computer user (likely Field) clicked on the cached versions. Field maintained that the caching of his work violated his copyright and sued Google for statutory damages to the tune of $\$ 2,550,000$ (\$50,000 per work). Field admitted in his deposition that this was all by design; Field did this specifically to make money off of Google's standard practice.

The court granted summary judgment for Google on multiple sufficient grounds. After finding no direct infringement, the court held even if there were direct infringement, Field impliedly licensed the copying, Field was estopped from asserting infringement, and Google's conduct constituted fair use.

\footnotetext{
* Thanks to Andrew Gold, John Harrison, Dennis Klimchuk, John Oberdiek, Rich Schragger, and Alec Walen for comments on the draft manuscript, and to Molly Brady and Alli Herzog for enduring endless discussions about estoppel. This paper further benefited from presentation at the Rutgers Institute for Law and Philosophy's Civil Wrongs and Justice Conference.

${ }^{1}$ Nate Anderson, Judge: Google Cache Kosher When It Comes to Copyright, https://arstechnica.com/uncategorized/2006/01/6063-2/ (last visited May 29, 2018)(quoting Blake Field). Poems by Blake Field are no longer accessible.

2412 F. Supp. 1106 (D. Nev. 2006).

${ }^{3}$ Like his burrito, these poems were quickly produced. He wrote all fifty-one during a three-day period. Id.
} 
It is hardly surprising that Field lost. And, it is hardly surprising that a court would rest its decision on multiple, alternative grounds. What is perhaps more surprising is that the legal defenses hardly fall into clear and coherent categories. And, it seems difficult in some ways to put our finger on precisely why it is that Field should lose. Take consent. ${ }^{4}$ Did Field consent to the copying? Field would claim that he certainly wasn't consenting-indeed, his very goal was to be able to assert that Google wronged him - something that would be impossible if he had consented. ${ }^{5}$ Moreover, we might wonder whether the doctrine of apparent consent-that it reasonably appeared as though Field was consenting-is also missing the point. If our autonomy interests undergird consent, then the idea that you can consent just because someone else forms a reasonable belief about you seems odd. Moreover, given that apparent consent can apply to innocent agents from whose behavior another "reads" consent, this explanation does not seem to capture Field's culpability in luring Google into a potential copyright violation.

Then there is estoppel. One might think that estoppel is about being precluded from asserting your rights. Its origin is estopper, to stop, hinder, or bar. ${ }^{6}$ The court seems to hew to this more traditional understanding of unassertability. But if viewing Field's conduct as consent seems overbroad, estoppel seems too narrow. Does silencing Field's complaint really capture what is at stake?

Doctrinally, both consent and estoppel seem to lack a conceptual core. If consent is the exercise of a normative power predicated on our autonomy interests, then sometimes what we call "consent" is not really consent. And if estoppel is about barring/stopping/hindering one's ability to make a claim, but not about changing the underlying rights and duties themselves, then sometimes what courts deem to be estoppel is not really estoppel. Instead, consent has alternative normative groundings, and estoppel seems to be employed as the term by which courts can simply reach what they deem to be the fair or equitable result. Indeed, one state supreme court justice urged a "make your own estoppel approach" to reach what he deemed to be a fair conclusion. ${ }^{7}$ With myriad disparate labels sometimes referring to the same thing (consent, waiver, acquiescence, and license) and the same label referring to disparate things (estoppels covering several different sorts of legal relations), one quickly reaches the conclusion that Robert Stevens does: "English is not always a good language for conducting the business of law."

This paper aims to make sense of these categories, venturing into both consent and estoppel, but focusing more on the far more undertheorized estoppel. ${ }^{9}$ As it surveys these doctrines, it points to the sorts of changes in normative relations that appear to be at work and what might ground them. Ultimately, some of our practices make far more sense than others, although our nomenclature makes little sense at all. Apparent consent is not consent at all. And estoppel masks distinctions between

\footnotetext{
4 "An implied license can be found where the copyright holder engaged in conduct 'from which [the] other [party] may properly infer that the owner consents to its use." Field, 412 F. Supp. at 1116 (citations omitted). The doctrine operates as apparent consent does in tort law. Newman 2014, 518.

${ }^{5}$ To be sure, some will want to say that the intentional invocation of the normative power is itself consent. I discuss this in Section II.

${ }^{6}$ Merriam-Webster's Collegiate Dictionary 2003; Coke 1628, §667 (''Estoppe' commeth of the French word estoupe, from whence the English word stopped: and it is called an estoppel or conclusion because a man's owne act or acceptance stoppeth or closeth up his mouth to allege or plead the truth.").

${ }^{7}$ Robinson v. Fife, 3 Ohio St. 551, 557-58 (Ohio 1854).

${ }^{8}$ Stevens 2017, 126.

${ }^{9}$ Ben McFarlane's magisterial book on proprietary estoppel notwithstanding. McFarlane 2014.
} 
"forfeiture by insincere act" (a forced shift in rights and duties), other cases that should be deemed exercises of normative powers, other instances that should be seen as tort-like for creating liabilities, and thinner losses of the ability to complain/assert one's rights. Even this final forfeiture of mere assertability proves questionable because when it does not camouflage a more significant estoppel, it ultimately produces a result that may be disproportionate to A's behavior and B's reliance. Ultimately, I hope to show that our concepts are conflating radically different sorts of relations and that these labels prevent us from scrutinizing our practices as carefully as we should.

Before beginning, let me make one note about methodology. The objects of my inquiry range across myriad doctrines. Consent applies in torts and criminal law. Estoppel applies in law and equity, and its application spans from contracts to property claims to evidence. Some jurisdictions recognize doctrines that others do not, and which remedies are available may vary. In addition, theorists can take different approaches to doctrine. Some start with doctrine, and theorize bottom-up, so that their answers are significantly constrained by what the law is. Other theorists take a top-down approach, thinking more generally about principles, with a willingness to play fast and loose with actual doctrinal specifics. Although I intend to take doctrine seriously as the subject of our inquiry, my aim is more topdown normative than bottom-up doctrinal. That is, my goal is not to debate whether any particular doctrine is, say, better characterized as proprietary estoppel or a constructive trust, ${ }^{10}$ but rather to ask why it is that the rights and duties may or may not have changed. ${ }^{11}$ Moreover, although there are questions about whether and how law reflects morality, I take the ultimate object of my inquiry to be moral relations, not legal ones. Law may mirror morality imperfectly, but I will proceed with the assumption (and defend it as well) that these are not solely constructs of law.

\section{Consent}

Consent is the exercise of a normative power that changes rights and duties. ${ }^{12}$ Whether the best theory of the ontology of consent is that it is a mental act, a communication, or something in between, ${ }^{13}$ the idea is that one can drop a claim right that one otherwise has that another person not touch one's person or property, thus creating a Hohfeldian liberty. ${ }^{14}$ When I consent, your touching me is not battery and your entering my home is not trespass. The grounding of consent is typically thought to be the actor's autonomy interest. ${ }^{15}$

Despite consent's paradigmatic core, we quickly find a vast periphery. We sometimes take it that consent to one act is sufficient to constitute consent to another. They are, as Ken Simons notes, a

\footnotetext{
${ }^{10}$ Compare Stevens 2017, 134-36 with McFarlane 2014, 81.

${ }^{11}$ Take, for instance, what is called the "improving trespasser." A and B are neighbors. B believes A's land is his own and builds a garage on it. B has trespassed and improved the property. Does this ground a claim of unjust enrichment? Forced sale? Or might it be a case of estoppel by acquiescence? It is less important to designate the case as one of unjust enrichment or proprietary estoppel than it is to ask: "Does the property right in the land to shift from $A$ to $B$ ?"

12 Owens 2012, 165.

${ }^{13}$ Ferzan 2016 (mental act); Dougherty 2015 (communication); Tadros 2016, 209 (attempted communication).

${ }^{14}$ Westen 2004, 334.

${ }^{15}$ Alexander 1996, 165; Ferzan 2016, 404-5.
} 
"package deal."16 Sometimes the package is conceptual. To consent to playing football just is to consent to being tackled. Sometimes the package is more normative. You can understand what it means to get on a subway without getting jostled by your fellow passengers. Indeed, one can imagine a norm whereby one is not permitted to touch one's fellow passengers. And yet, there is no way to opt out of the package. You simply cannot get on a bus, wear a sign that says, "Don't touch me," and then sue anyone who touches you for battery. By getting on the bus, we take you to be consenting to the touching. Because the underlying justification for at least some of these practices may be distinct from the grounding of actual consent in autonomy, Beth Valentine argues that we ought not to call it consent. ${ }^{17}$ Valentine argues that "[b]ecause these other values may be in tension with autonomy, we ought to be explicit that such cases do not involve consent and its common justification." 18

Those cases, however, are not the most worrisome. The most worrisome culprit is "apparent consent." Apparent consent is not consent at all. Consider the most rcent draft provision for the Restatement (Third) of Torts:

\section{§16. Apparent and Presumed Consent ${ }^{19}$}

An actor is not liable to a person for otherwise tortious intentional conduct if either apparent or presumed consent exists.

(a) Apparent consent exists if the actor reasonably believes that the person actually consents to the conduct, without regard to whether the person actually consents.

The lumping of this phenomenon with other consent doctrines is justified by the drafters as follows:

The narrower view of reasonableness treats the apparent consent doctrine either as a kind of estoppel or as justified by the plaintiff's misleading the actor: plaintiff by his own words or conduct has created the misimpression that he or she actually consents. The broader view endorsed by this Restatement, by contrast, better furthers the policies that the apparentconsent doctrine promotes, because it precludes liability whenever the defendant is without fault in mistakenly believing that the plaintiff actually consents, and it facilitates, to a greater degree, the social benefits of mutually advantageous human interactions. ${ }^{20}$

This commentary follows a hypothetical modeled on the $O^{\prime} B$ rien case in which the plaintiff was required to be vaccinated to enter the United States. ${ }^{21}$ She held her arm up, was vaccinated, and then sued. There, the court held that apparent consent is consent. If a reasonable person believes your behavior constitutes consent, then you are consenting.

Let's be clear about what the commentary claims. Instead of drafting the apparent consent provision as grounded in the fact that the plaintiff's own words or conduct are the cause of the

\footnotetext{
${ }^{16}$ Simons 2014, 283.

17 Valentine 2017, 520.

18 Id. at 500 .

${ }^{19}$ American Law Institute 2018.

20 ld. at 81.

${ }^{21}$ O’Brien v. Cunard Steamship Co., 28 N.E. 266 (Mass. 1891).
} 
defendant's reasonable belief, the provision is drafted more broadly. It thus "precludes liability whenever the defendant is not at fault" for his mistaken belief. If the defendant is not at fault for his mistaken belief, then the plaintiff is deemed to have consented "without regard to whether the person actually consents." 22 Hence, by the drafters' own lights, lack of culpability is being treated as a lack of wrongdoing.

As a matter of conceptual categorization, this should strike us as a bit astounding. A plaintiff, even one who does nothing to encourage the defendant's reasonable belief, is deemed to have consented. Here are three troubling implications of calling this "consent." First, it raises questions about whether the plaintiff, or a third party, can stop the defendant's conduct as a matter of selfdefense. If the doctor only reasonably believes that the plaintiff consented to the shot, but she has done nothing to mislead him, shouldn't she be permitted to knock his hand away as he comes at her with a needle? Second, even as a matter of labeling, we should be worried about employing consent in ways that are not autonomy affirming, as it creates the potential for conceptual bleeds that lead to us employing the term consent when what is doing the work is entirely different normative justification, as Valentine notes. ${ }^{23}$ Third, to the extent that we take consent to be an act of will, the plaintiff is subjected to a judgment that she may feel is completely at odds with her choices-another's mistake becomes something she has chosen.

We should be clear: the doctrine of apparent consent captures cases that are not consent at all. If someone else (reasonably) believes you have changed your rights and duties, that is insufficient to constitute an alteration of your rights and duties. There is no exercise of the actor's autonomy from which we can say that the normative power has been invoked. If $B$ reasonably believes that $A$ consented to a touching but A did not, there would be nothing odd about A saying, "Why are you touching me?" The fact that B believes A consented may appropriately yield that B ought not to be liable for damages. But this, then, is about the B's lack of culpability. There is no consent in "apparent consent."

Undoubtedly, apparent consent absolves Google of responsibility for copyright infringement (at least insofar as requiring people to speak up with metatags is a justifiable background practice). But we should see that consent does very little work here. Apparent consent ought to lead to the conclusion that Field did not change his rights and duties; Google just reasonably believed he had.

\section{Forfeiture by Insincere Act: A Mechanism of Consent?}

I suspect that few people think that Field did not change any of his rights and duties. His entire goal was to trick Google into wronging him so that he could recover damages. And the court rightly denied that this was possible. ${ }^{24}$ The question, then, is what is the most perspicuous account of why it is

\footnotetext{
${ }^{22}$ American Law Institute 2018 , § 16.

${ }^{23}$ Valentine 2017.

${ }^{24}$ This is not to say that it is never possible to lure someone into wronging you. It depends on whether "forfeiture by insincere act" applies. It will not apply when the actor is justified in creating the misimpression. Ferzan 2017, 190-91.
} 
that Field was not wronged. The doctrine of apparent consent gets us there at the expense of being woefully overinclusive, as it conceives of nonculpable wrongdoings as no wrongs at all.

What is going on in Field's case, I submit, is a forfeiture, specifically "forfeiture by insincere act." This forfeiture has been camouflaged by our deployment of "consent" and "estoppel," such that this altogether different rationale for shifting rights and duties has been obscured. Forfeiture by insincere act obtains when we culpably, and without justification, mislead other people into believing that we are exercising a normative power. ${ }^{25}$ Where rights would otherwise be dropped or waived, the insincere act results in that right being forfeited, and where duties would have been created, that duty is, in Lee Fennell's term, "forced." 26 Although the law may not speak about "forfeiture" with much frequency, this sort of mechanism for shifting rights and duties is apparent in other areas. For instance, culpable aggressors are thought to forfeit their rights against defensive force. ${ }^{27}$ Criminals forfeit rights, such that the harm from punishment does not wrong them..$^{28}$ Indeed, even the idea that an actor has unclean hands and thus loses her ability to make an equitable claim seems partially grounded in the idea that one's wrongdoing results in the loss of one's (here, enforcement) rights. ${ }^{29}$ Hence, even if we do not directly label something as forfeiture at the level of doctrine, the underlying operation is the involuntary loss or suspension of a right. Field's behavior in trying to convince Google that he was consenting while "crossing his fingers behind his back" counts as consenting, not because he was exercising the normative power of consent in its typical way, but because the change in normative relations was forced upon Field. He forfeited his right through his insincere act.

The reason why this forfeiture shifts rights and duties is because individuals have interests in not wronging others, ${ }^{30}$ and what insincere actors do is to attempt to trick others into wronging them. Forfeiture by insincere act denies insincere actors the ability to have it both ways, to lure a person to cross one's boundaries and then to complain about the boundary crossing. It recognizes that when someone relies on such representations by an insincere actor, that reliance makes the actor normatively vulnerable to judgments that he is a wrongdoer. The shift of the rights and duties is the way (though not necessarily the only) to remedy that reliance.

In our legal discourse, the underlying mechanics of "forfeiture by insincere act" have been subsumed under both consent and estoppel. This is problematic. In this section, let us consider the blurring of this forfeiture with consent. In the next section, I will discuss estoppel.

One might object that all consent, and other normative powers such as abandonment, require is the intentional invocation of the performative "yes" or "I abandon" and not the sincere statement of

\footnotetext{
${ }^{25}$ Ferzan 2017, 184-87.

${ }^{26}$ Fennell 2014.

${ }^{27}$ McMahan 2009, 10.

${ }^{28}$ Wellman 2017, 34.

${ }^{29}$ Ori Herstein takes part of the justification for the clean hands doctrine to be punishment. Herstein 2011 . I am less convinced that we need to characterize the forfeiture as a punishment to understand why enforcement right is lost. There is also a debate whether forfeiture is the most perspicuous way to understand some of these losses. Some scholars prefer terms such as "suspension."

${ }^{30}$ Ferzan 2017, 184; Tadros 2016, 1. This claim may seem too self-interested to some readers. I have a reason not to want to wrong others because I should not want to wrong others, not because I do not want to be a wrongdoer. I concur that in most cases, one's reasons are focused on the "victim" and not on oneself. But recognizing this is insufficient to deny that we have some interest in not being a wrongdoer as well.
} 
that intention. Although I question the doctrinal (and underlying moral) accuracy of this claim, ${ }^{31}$ more importantly, let me suggest that what grounds the intentional act view is actually two disparate mechanisms. That is, what grounds the shift in rights and duties when one means what ones says may diverge from what grounds the shift in rights and duties when one insincerely invokes the normative power. The estoppel-like features that force the change of rights and duties on someone bear little resemblance to the autonomy expressing sincere invocations. We enforce fingers-crossed promises for different reasons than we enforce sincere ones. After all, when we truly intend to promise, consent, or abandon, we exercise our will to achieve the goal we want. But the enforcement of insincere acts cannot be predicated on the same sort of alignment of act and will. Instead, we have an alternative reason to make the statement true. For instance, Jody Kraus argues that promisees cannot distinguish sincere from insincere promises such that if insincere promises only entitled the promisee to reliance, as opposed to expectation damages, the promisee would never know the true value of the promise. ${ }^{32}$ Accordingly, we treat both as promises.

Even if we conjoin both the sincere and the insincere under one normative power, however, we may need to disentangle these independent justifications if we are faced with the question of the efficacy of one of these invocations when the speaker was justified or excused. That is, when one consents for a good reason, then the consent looks morally valid and unproblematic. But if one fakes consent for a good reason, then we may doubt that the forfeiture principle should be in play. This means that we will have different practical implications depending upon the mechanism. Hence, those who aim to conjoin forfeiture by insincere act and true consent may find that they will need to pry the two apart to deal with different cases. We should thus recognize that one term may actually be covering two very different ways that rights and duties are changed. For these reasons, forfeiture by insincere act should be recognized as shifting rights and duties in the same way as the mimicked normative powers but for very different reasons. Saying Field consented misses why he is no longer wronged.

\section{Forfeiture by Insincere Act: A Form of Estoppel?}

Even if we ought to be wary of treating these forfeiture by insincere act cases as consent, we might wish to ask whether we should count them as estoppels. In that previous work, I dismissed that what was going on was estoppel. But perhaps that was too quick, as I had ignored the myriad disparate ways that estoppel can be instantiated. In fact, if we follow the Ohio Supreme Court justice's advice to "create your own estoppel," then perhaps I was just suggesting that there was another estoppel out there. However, to deem forfeiture by insincere act as a case of estoppel may be to paint with too broad a brushstroke. What does estoppel mean anyway?

Here is where we need even more ground clearing. This is because just as apparent consent is not consent, many estoppels are not really estoppels at least insofar as we want estoppel to capture something about the inability to assert a right. Indeed, it is just downright confusing to have doctrines that do different things have the same name. Some estoppels alter the underlying rights and duties, just

\footnotetext{
${ }^{31}$ Abandonment, in particular, appears intention-centric at the level of doctrine. See, e.g., Linscomb v. Goodyear Tire Co., Inc. 199 F2d 431 ( $8^{\text {th }}$ Cir. 1952).

32 Kraus 2009, 1621-24. For the argument that my account better explains the phenomenon he identifies, see Ferzan 2017, 197-99. In private conversation, Kraus has suggested that he may take these arguments on board as friendly amendment to his position.
} 
as forfeiture by insincere act does. Some estoppels appear to create liabilities. And the estoppels that are true to their name only alter our enforcement rights. Maybe we ought to give up the idea that estoppels actually silence complaints, but if that is true, we will still need to revisit whether the disparate relations all ought to have the same label.

My goal here is not to systematize the entirety of estoppels. Nimmer mentions five for copyright. As he puts it, "The legal rubric of estoppel serves as something [of] a chameleon." ${ }^{33}$ Ben McFarlane delineates three types of "proprietary estoppels." ${ }^{34}$ From promissory estoppel to collateral estoppel, estoppel has become an extraordinarily promiscuous legal category. ${ }^{35}$

Rather than fully systematizing, let's hone in on three general instances of estoppel that we ought to be concerned with if we are concerned with when individuals are potentially wronged. First, I will address the Field court's estoppel, which I contend is best understood as forfeiture by insincere act (call this "forfeiture estoppel"). Then, I will turn to estoppels that are liability creating and tort-like (call this "reliance estoppel"). ${ }^{36}$ Finally, we can turn our gaze to the estoppel that does not alter the underlying Hohfeldian relation but instead alters our ability to enforce it (call this "assertability estoppel").

Let us return to forfeiture by insincere act. Field was estopped because according to the court, "Field knew of Google's allegedly infringing conduct"; "Field intended that Google rely upon his conduct or acted so that Google had a right to believe it was so intended"; "Google was ignorant of the true facts"; and "Google detrimentally relied on Field's conduct." ${ }^{37}$

Let's be clear. Field misled Google into believing that Field was consenting. He sought to mimic the behavior of exercising the normative power of consent while denying that he was doing so. But was he wronged?

I have claimed that in instances such as these, someone like Field is not wronged. When one recklessly misleads another into thinking that one has exercised a normative power, the rights and duties do shift just as they would with the actual invocation of the normative power. If O'Brien crossed her fingers behind her back but knew the doctor would take the raising of her other arm to mean that she was consenting, then O'Brien forfeits her rights to the same extent as actual consent. So, too, faking abandonment can count as abandonment.

If you say it, and don't mean it, then what you are doing looks quite a bit like some forms of estoppel. You are misleading someone to his detriment. What is important to recognize is what the detriment is. We often think that the detriment is that a person has forgone a business opportunity or has built a shed or has purchased a piece of property. However, sometimes the detriment is different. Were the rights and duties not to change when someone relies on your misleading invocation of a normative power, that person's reliance would result in that person wronging you. Accordingly, the

\footnotetext{
${ }^{33}$ Nimmer 2009, § 13.07.

34 McFarlane 2014.

${ }^{35}$ Accord Stevens 2017, 129.

${ }^{36}$ Accord Zipurksy 2014, 153.

37412 F. Supp. at 1116.
} 
person would be worse off. The doctor does not just want to be able to give O'Brien the shot. He wants to be able to give her the shot without wronging her.

Notice the space the forfeiture by insincere act opens up when we are talking about Field. We are able to account both for Field's culpability and Google's detrimental reliance. It has estoppel-like features that render it to have consent-like effects. Field does not simply lack a right to complain or sue. The underlying right is implicated.

Indeed, consider those cases in copyright in which estoppel applies. In Keane Dealer Services, the plaintiff argued that the defendant's reliance ended when the suit was filed. ${ }^{38}$ This sounds like reliance or assertability estoppel, which I discuss below. The court demurred, holding that with estoppel, "the holder's rights may be destroyed." ${ }^{39}$ The court destroyed the right, all the while noting that "[e]stoppel is a drastic remedy and must be used sparingly." ${ }^{40}$ This is none other than a forfeiture principle, stepping in to treat the plaintiff's misleading behavior as an abandonment.

The idea here, then, is that there will be cases that we may currently label estoppel that seem to miss the point. The point is that what the actor has done is to effectively shift the rights and duties in the same way that sincere invocation of the normative power would have shifted the rights and duties. But as I argued in the previous section, if we deem these acts as just consent or abandonment without further scrutiny or concern, that may miss the point too, as the grounds for counting insincere acts as invoking a normative power may depart from the grounds for why sincere invocations are normatively efficacious. And, that distinction could make a difference in some cases.

Ultimately, when we attend to the underlying reason rights and duties shift, we may find that there is something amiss with saying that an act is estoppel (which at least initially seems to be about assertability) and something amiss with saying that an act just is consent or abandonment. To the extent our current practice calls these cases "estoppels," it threatens to blur acts that change rights and duties with acts that only give rise to reliance damages or bars to assertability (as I discuss below). ${ }^{41}$ And to the extent that we simply sweep these actions under the label of the normative power they mimic, such as consent or abandonment, we threaten to fail to attend to when the two might come apart, such as when the person is justified in causing a misimpression.

The lesson of the Field case is that we want some sort of label to capture those instances in which someone is not wronged because rights and duties have changed. Although we continue to use "estoppel" promiscuously such that it captures forfeiture by insincere act cases, the question is how well that sits with the other estoppels that are out there.

\section{Reliance Estoppel}

One objection to viewing Field as having altered his rights and duties through estoppel is that it is often thought estoppel does not change rights and duties. Indeed, one of the puzzles that appears to

\footnotetext{
${ }^{38}$ Keane Dealer Services, Inc. v. Harts, 968 F. Supp. 944 (SDNY 1997).

39 Id. at 947.

40 ld. at 948.

${ }^{41}$ It is true that I take forfeiture by insincere act to be a particular remedy for a particular sort of induced reliance. But we ought to be clear about when the rights and duties change and when they do not.
} 
permeate some of the UK's treatment of proprietary estoppel is the tension between treating estoppel as forfeiture like and treating it as liability generating. Of course, neither of these invocations of estoppel are about simply about silencing parties, which means they are both extensions of estoppel's original core. Still, we might ask what the doctrines are trying to do.

Ben McFarlane has helpfully delineated three types of proprietary estoppels. ${ }^{42}$ Estoppel by acquiescence wherein A acquiesces in B's mistaken belief about B's rights; estoppel by representation wherein $A$ represents a fact or law and $B$ reasonably relies and will be harmed were $A$ to be able to deny the truth of his representation; and estoppel by promise wherein $A$ promises $B$ an interest in land and $B$ detrimentally relies. It is the first and third that are of interest to us presently. They are the two doctrines that straddle normative powers and liability. The second, concerning assertability, will be considered later.

Take the first type of case. I know you think something is yours, but it is mine. I allow you to believe it is yours. I say nothing. You rely to your detriment. Why shouldn't it just become yours?

Now, this may be a point at which there is a divergence between law and morality. Maybe law needs more trappings of property transfer than morality does. Think of how hard it is to transfer a car. We would not want defendants to be able to drive off with cars and defend by claiming that the plaintiffs just did not say anything. Still, we ought to ask the question whether at the moral level, rights and duties shift in these cases. If you do not say anything when someone is trespassing, or you don't protect your things from someone else, why not think that the rights and duties will shift whether you like it or not?

But we ought not to be too hasty. Unlikely laches or adverse possession, this sort of estoppel applies quickly. No duration is required. And the beneficiary of proprietary estoppel is honestly mistaken. He thinks it is his property to begin with. So, A need not sit on his rights for some set duration, and $B$ has to think it is his property. Put this way, why would we think that $A$ would lose his right? Why must he rescue $B$ from wronging him such that if he fails to do so, B now owns the property?

I suspect that one concern in the background is the question of why $A$ is sitting on his rights while $B$ is violating them. If $A$ sees $B$ building a shed on A's land, why wait to say something? In many cases, $A$ may be behaving opportunistically ${ }^{43}$-if he could complain later, he would own a new shed! Or perhaps we think it is wrong to sit by and let others violate our rights if we do intend to assert them. Perhaps we are being "sticklers in a bad sense" or abusing our rights if we wait until someone has violated our rights and then say, "Aha! Gotcha!" 44 The situation makes it hard to imagine that A has anything but a bad motive if he knowingly sits by and watches his rights be violated only to assert them later (presumably for some sort of benefit). ${ }^{45}$

\footnotetext{
42 McFarlane 2014.

43 Smith 2015.

${ }^{44}$ Aristotle 1962, 142; Klimchuk 2014.

${ }^{45}$ Consider the facts of Petrella v. Metro-Goldwyn-Mayer, 572 U.S. 663 (2014) wherein the plaintiff did not assert her copyright in the screenplay to the movie, Raging Bull, between 1991 and 2009 and because it was not making money. There, the Supreme Court held that laches no longer applied in light of the statute indicating when suits may be brought. But the Court still noted that the defendant could be protected and retain the return on its investment in marketing the movie.
} 
So, A sits on his rights for bad reasons. Does this change A's rights? As I argued above, we might think that the only thing that rescues $B$ from otherwise having wronged $A$ is for the underlying rights and duties to shift. On the other hand, unlike cases in which A tricks B into wronging him, all $A$ does is fail to say something. For this reason, we might think it is extreme to think $B$ ought to be protected from his own innocent wrongdoing by acquiring A's property; A didn't trick him. It is one thing not to owe A damages; it is another thing for his innocent mistake to be made true. It seems disproportionate to A's behavior to have A forfeit his rights.

If we are not going to deem A's acquiescence to be the exercise of a normative power (or a forfeiture), we might still want to protect poor, innocent B. As Ben Zipursky notes, "While the inducing of reliance is not a wrong, the failure to perform (given the reliance and its foreseeable impact), is a wrong." ${ }^{\prime 6}$ Here, then, the idea of focusing on B's reliance may make sense. That is, the law does not give $B$ a right because $A$ misled him, but gives $B$ the right only insofar as is necessary to protect his reliance interest. If $A$ finds a way to rescue $B$ from his reliance without surrendering the right, the law will deem this sufficient.

To probe this reliance account further, consider McFarlane's third type of case. Assume that A tells $B$ that if B moves to A's estate and takes care of A and his land, that B may have A's land when he dies. A dies but leaves the land to $C$. What recourse does $B$ have? An outsider to the law (and particularly to UK land law) might have thought that it is simply a no brainer that B gets the land. A promise is a promise. But alas, law has never simply enforced promises, and so we see that what happens is that B's behavior gets treated as a trust fall: A says, "lean back and I will catch you" and B relies. A does not catch $B$, and $B$ gets the damages of his detrimental reliance. Those damages do not require $A$ to make good on his promise, but rather treat $A$ as having created a liability to prevent $B$ from being harmed because $B$ believed $A$. And, thus, $A$ can make good on his representation by avoiding the detriment even if doing so is not by doing the very act that $A$ promised. In some cases, $B$ may win the land, but that is not always true. Accordingly, this form of estoppel, like estoppel by acquiescence, does not count as the exercise of a normative power, but rather, a duty to rescue for having been the person to create the peril at the outset. It also extends far beyond assertability estoppel. This isn't about silence a complaint by $A$; it is substantive in providing a remedy to $B .{ }^{47}$

My point here is not that this tort-like liability is normatively unjustifiable. Rather, the question is what we should understand the estoppel to be doing. I argued above that some estoppels are truly forfeitures by insincere act. Those sorts of estoppels change rights and duties. But the first and third types of proprietary estoppel are functioning in an utterly different way. Their rationale seems to be predicated upon reliance by B and A's better position to manage that risk.

However, if we did not simply label these items as estoppels, we might make better progress at understanding the underlying mechanics. Stevens argues that many cases do require meeting the plaintiff's expectations, and not just managing the plaintiff's reliance, and he sees these cases as a species of constructive trusts. Indeed, to the extent that one begins with the idea that promises do create moral duties, it seems that the case for a property transfer in the promising cases is even stronger than it is in acquiescence cases. Those who believe there is a duty to fulfill one's promises, as

\footnotetext{
${ }^{46}$ Zipursky 2014, 153.

47 Stevens 2017, 133: “' [P]roprietary estoppel' has been used to create a much more expansive liability-creating rule which is nothing to do with anyone being estopped from asserting anything."
} 
opposed to just protecting the promisee's reliance interest, are unlikely to be satisfied with the court's handling of these promissory estoppel cases. They are likely to think that the rights and duties are rightly changed by the exercise of the normative power of promising. This shift then would not be a forfeiture. It would be the actual exercise of the normative power of a promise.

This is not a shallow puzzle or just a linguistic debate. We would need to think more about whether these cases are best understood as a form of forced shifting of normative powers, a voluntary shifting of normative powers, or whether they are best understood as liability generating. Even if we agree that what is centrally at stake is the defendant's faulty creation of the plaintiff's vulnerability, we may want to attend more carefully to whether we can and should allow flexible remedies depending upon the equities or whether these cases are better understood as generating a more binary forcible or voluntary shifting of rights and duties.

\section{Assertability Estoppel}

After we trim our estoppels, we come to assertability estoppel. Stevens summarizes this form of estoppel (properly called "evidentiary estoppel") as, "When A makes a clear and unambiguous statement of fact to $B$, intending $B$ to rely upon such a statement, and $B$ believed the truth of the statement and acted upon it, $A$ is estopped from proving the fact is false." ${ }^{48}$ The impact of this is that "the [c]ourt will not allow the representor to adduce evidence which contradicts the truth of the representation that it has made. The legal relationship between the parties is then assessed according to the facts as represented and not according to the true states of affairs." ${ }^{\prime 9}$ This form of estoppel does not bind third parties to whom the representation was not made. ${ }^{50}$

In this volume, Larissa Katz seeks to understand the grounding of assertability estoppel. She imagines a case where $B$ rides off on a bicycle that belongs to $A$, but $A$ tells $B A$ is not the owner. He does so "without at the same time intending to or taking steps to abandon [his] claim to the bicycle. The right remains with $[A]$ in that case. ${ }^{\prime 51}$ In Katz's case, then, A owns the bike but is estopped from asserting it. To Katz, the puzzle is how to understand a doctrine that allows judges to make decisions about private rights in contravention of the readily available truth about those rights. That is, it is easy to ascertain the bike belongs to $A$. What could justify allowing courts to come to a conclusion that "fail[s] to track the truth about our private rights[?]"52 Katz's answer is that right holders have "qualified power[s] to take [their] own rights out of controversy and in that limited sense then to determine them for purposes of private ordering." 53

Katz and I are troubled by different things. Perhaps because I am an evidence teacher, the idea that there might be good facts that a plaintiff or defendant is barred from introducing is untroubling to

\footnotetext{
48 Stevens 2017, 128.

${ }^{49}$ Wilken and Ghaly 2012, 136.

${ }^{50} \mathrm{Id}$. at 188 (although actors in privity may be bound).

${ }^{51}$ Katz this volume, 12 [draft manuscript page].

52 Id.at 3.

53 Id. at 5.
} 
me. Lots of attainable truth does not make it into the courtroom or into a decision. In the realm of evidence, the question really turns on whether the underlying policy is a good one.

I also wonder whether the litigation prism is the correct one. To be sure, this sort of estoppel appears in court, but I suspect this rule has a deeper moral underpinning. That is, assume that $A$ says to D, "That jerk, B, just rode away with my bike!" I take it that D might say to A, "This is all your fault for telling $B$ that it was not your bike!" If this is so, then the idea that A has no complaint is not a legal idea; it is a moral one. ${ }^{54}$

Contra Katz, I maintain that we should understand assertability estoppel as the moral loss of an enforcement right. We can lose our enforcement rights without losing the underlying right. Consider the provocateur. ${ }^{55}$ Criminal statutes often disallow the use of defensive force if the "defender" is the person who provoked the fight. The provocateur is distinguishable from an initial aggressor, as someone may provoke a fight without actually placing the other person in fear of a rights violation. And, unlike an aggressor, against whom defensive force is justified, a provocateur is wronged by the use of force. I may call your mother a bunch of names to provoke you, but you still wrong me if you hit me. Nevertheless, when specific conditions apply, I am barred from using force to stop you from hitting me. Hence, what the provocateur and the estopped actor have in common is that they lose a standing to complain about being wronged (and lose the ability to prevent being wronged) while still being wronged. ${ }^{56}$ That is, before we get to courts or rights determinations, our ordinary moral notions seem to capture much of what is going on with estoppel - one's underlying right (not to be hit, to possess one's bike, etc.) is simply naked and unprotected.

Katz's case, I submit, is actually an instance of forfeiture by insincere act. Its intuitive pull is not because of assertability estoppel. To see this, let's develop Katz's case a bit. Assume that I own the bike and a person (call her Larissa) walks down the street. My neighbor has cleaned out his garage and a bunch of bikes are on the curb with a note, "Free. Take a bike!" I have just ridden my bike home and have stopped with it on the curb, near my neighbor's pile. Larissa eyes my bike - perhaps it's the cotton candy color, or the lavender streamers coming out the handle bars, or the white wicker basket with flowers-and she decides that is the one she has to have. She asks, "Is that your bike?" And I say, "No." (Why? I don't know. Maybe I am in an odd mood, like the mood one would have to be in to imagine owning a pink bicycle with lavender streamers and a wicker basket.) In any event, Larissa happily pedals away.

As I argued above, some acts of misleading others to wrong us ought to change our rights and duties. Forfeiture by insincere act applies here. Larissa now owns her bike. So, we might think that Katz's hypothetical shows us that we should not assume that estoppel by representation is always just estoppel by representation. My underlying conduct does more than forfeit my failure to complain, and we ought to have the legal mechanisms to recognize that. At the moment, assertability blends into the underlying right when we ought to keep them separate. Indeed, we do see the blurring of doctrines, such as in Hopgood v. Brown, wherein the court simultaneously purports to view the case as one of estoppel by representation (assertability estoppel) - a rule of evidence-and at the same time to think

\footnotetext{
${ }^{54}$ Accord Cornell 2016.

${ }^{55}$ Ferzan 2013. Cornell also uses this example, though I would say that the person who insults another is the provocateur, not the person who throws the first punch. Cf. Cornell 2016, 1149.

${ }^{56}$ Cornell 2016.
} 
that the property interest has changed in a way that is binding on third parties. ${ }^{57}$ Commentators criticize this case as confused. ${ }^{58}$ Employing the term estoppel creates confusions as to which rules apply because different forms of estoppel are grounded differently.

And, not all assertability estoppels are forfeitures by insincere act. Sometimes, what is said cannot possibly alter rights and duties. Other statements of fact can estop. So, we are now finally at assertability estoppel-the very thing most people mean when they say "estoppel."

We ought to be in awe at the expansiveness of this doctrine, this core estoppel that we so easily take for granted. For one thing, culpability does not matter. You do not even need to know that the fact you are asserting is wrong. Maybe you don't think the bike is yours. It doesn't matter. You lose the right to assert you've been wronged irrespective of whether your prior statement was made in complete good faith. Indeed, unlike estoppel by acquiescence in which we might think that an illicit motive almost always is present when the elements are met, we can easily imagine getting the facts wrong.

Moreover, contrary to other estoppel doctrines, in which reliance may be protected without granting B's expectations, estoppel by representation gives B the benefit of his expectations, at least insofar as it does not look at whether B's reliance interest could be protected with something less than a complete bar on introducing evidence..$^{59}$ A loses full assertability even if the equities might opt for some baby splitting. Now, this doctrine is a legal doctrine, and not a mere equitable one, but even in its equitable instantiation it takes this robust form. ${ }^{60}$ Like apparent consent, A loses the entirety of a right (here, her enforcement right), as opposed to other estoppel doctrines wherein, at least sometimes, B only gets her reliance protected. ${ }^{61}$ So, while other estoppels lean more toward reliance than forfeiture, assertability estoppel is itself a forfeiture doctrine, and a broad one at that.

As an example, consider a hypothetical case based on Avon CC v. Howlett. ${ }^{62}$ A overpays B by $\$ 1000$. B, believing the amount to be correct, spends $\$ 500$ on credit card bills and groceries. A realizes the mistake and sues. Estoppel would yield that $B$ need not repay any of the money. But why not require $B$ to give back the unspent $\$ 500$ ? A is completely silenced, and B gets to keep $A^{\prime}$ s money, even beyond any reasonable reliance on $B^{\prime}$ s part.

Let us take stock. For forfeiture estoppel, A is actively misleading B into wronging him; thus, forfeiture by insincere act steps in and shifts the rights and duties. For reliance estoppel, A's behavior

57 [1995] 1 WLR 213.

${ }^{58}$ E.g., McFarlane 2014, 509; Wilken and Ghaley 2012, 191-92.

${ }^{59}$ Laycock 2010, 946.

${ }^{60}$ Wilken and Ghaly $(2012,138)$ observe:

If the doctrine is purely evidential, the only possible outcome is that the representor is prevented from denying the truth of what it has represented. There is no intermediate position or alternative remedy. This may be inflexible in terms of both analysis and remedy.,,, [Avoiding the inflexible approach], restitution-based thinking could lead to a more broadly and substantively based 'minimum equity' concept that in turn leads to a unified doctrine of estoppel.

Yet they find the "weight of authority" is against such a position and that "this logical approach would be, at present, heterodox." Id. at 138.

${ }^{61} \mathrm{Id}$. at 175 ("The consequence of holding the representor to its representation may result in a benefit to the representee which far outweighs the detriment it would have suffered if the representor were permitted to resile from it.") Wilken and Ghaly go on to note some cases that appear to depart from this harsh rule. Id. at 178-79. 62 [1983] 1 WLR 605 CA. 
gives rise to reasonably reliance on B's part, and A must "rescue" B from B's peril. This is a less robust shift as it does not entitle B to A's property, just to reliance damages. For assertability estoppel, we would expect it to be weaker still, as it only governs A's abilities to assert his rights. And yet, with the teachings of the other estoppels in hand, we might question the fairness underlying this very core sort of estoppel we took for granted. Unlike the other two, we may rightly worry that there is an unfair strict liability element to this. And unlike reliance estoppel, assertability estoppel does not opt for baby splitting, equity, and protection of reliance; rather, it causes the forfeiture of A's right to assert his rights full stop.

Put in perspective, the ground level doctrine of assertability estoppel seems unjustified. In some cases, A knows he is making a misstatement, and in those cases, absent some good reason, A should be held to what he previously said. But in other cases, we may want to know more before we come to a conclusion. Sometimes both people are innocent. When both people are innocent, we have to ask hard questions. But there are plenty of doctrines in which B does not win. For instance, we do not allow good faith purchasers of goods to win over true owners. ${ }^{63}$ At the level of morality, nuance should matter. If I mistakenly believe the bike is one of the ones abandoned by my neighbor, only to discover that evening that he had left that one away from the pile as a gift for me, then perhaps I ought to have some standing to talk to Larissa and work something out. ${ }^{64}$ I ought to have the right to assert I've been wronged.

Conclusion

Why can't A assert that she's been wronged? Under the rubric of consent, she may be said to have truly consented or apparently consented. Under the rubric of estoppel, she may have forfeited the right, created a duty to rescue, or simply been silenced. Thus, there is far more to both consent and estoppel than one categorization. Attending to the details of the underlying normative relations reveals that we are grouping what we ought to split into doctrines with different normative grounds and different practical implications.

\section{References}

Alexander, L (1996) “The Moral Magic of Consent (II)" Legal Theory 2: 165-174.

American Law Institute (2018) Restatement of the Law Third Torts: Intentional Torts to Persons (Council Draft No. 5).

Aristotle (1962) Nicomachean Ethics (Ostwald, M transl.) (Englewood Cliffs, NJ: Prentice Hall, 1962).

\footnotetext{
${ }^{63}$ O’Keefe v. Snyder, 416 A.2d 862 (N.J. 1980).

${ }^{64}$ Moreover, we might ask whether Larissa should return the bike to me even she realizes I innocently misspoke. That is, the B's of the world may recognize that though they now act "within their rights," they ought to (aretaic "ought," and perhaps deontic "ought") return the property (or otherwise split the baby) in innocent estoppel by representation cases.
} 
Coke, E (1628) 2 The First Part of the Institutes of the Laws of England; or a Commentary Upon Littleton § 667 (Francis Harvgrave \& Charles Butler, eds., Dublin: Fleming and Phelan 1809)(1628)

Cornell, N (2016) “A Complainant-Oriented Approach to Unconscionability and Contract Law” University of Pennsylvania Law Review 164: 1131-1175.

Dougherty, T (2015) "Yes Means Yes: Consent as Communication" Philosophy and Public Affairs 43: 224253.

Fennell, L A (2014) “Forcings” Columbia Law Review 114: 1297-1372.

Ferzan, K K (2017) “The Bluff: The Power of Insincere Actions” Legal Theory 23: 168-202.

Ferzan, K K (2016) "Consent, Culpability, and the Law of Rape" Ohio State Journal of Criminal Law 13: 397-39.

Ferzan, K K (2013) “Provocateurs” Criminal Law and Philosophy 7: 597-622.

Herstein, O J (2011) “A Normative Defense of the Clean Hands Doctrine" Legal Theory 17: 171-208.

Katz, L (forthcoming, this volume) "Blowing Hot and Cold: The Role of Estoppel”

Klimchuk, D (2014) "Equity and the Rule of Law" in Private Law and the Rule of Law (L Austin and D Klimchuk, eds.), (Oxford: OUP, 2014): 247-268.

Kraus, J S (2009) "The Correspondence of Contract and Promise" Columbia Law Review 109: 1603-1649.

Laycock, D (2010) Modern American Remedies: Cases and Materials (Aspen 2010).

Merriam-Webster's Collegiate Dictionary (2003) “Estoppel” $\left(11^{\text {th }}\right.$ ed.)

McFarlane, B (2014) The Law of Proprietary Estoppel (Oxford: OUP, 2014).

McMahan, J (2009) Killing in War (Oxford : OUP, 2009).

Newman, C M (2014) “'What Exactly Are You Implying?': The Elusive Nature of the Implied Copyright License" Cardozo Arts and Entertainment Law Journal 32: 501-559.

Nimmer, M B \& Nimmer, D (2008) Nimmer on Copyright (New Providence, NJ: Matthew Bender) (Original work published 1963).

Owens, D (2012) Shaping the Normative Landscape (Oxford : OUP, 2012).

Simons, K W (2014) "Exploring the Relationship Between Consent, Assumption of Risk, and Victim Negligence" in Philosophical Foundations of the Law of Torts (J. Oberdiek, ed.) (Oxford: OUP, 2014): 272291.

Smith, H E (2015) “Equity as Second-Order Law: The Problem of Opportunism" (January 15, 2015). Available at SSRN: https://ssrn.com/abstract=2617413 
Stevens, R (2017) “Not Waiving but Drowning” in Defenses in Contract (A Dyson, J Goudkamp, and F Wilmot-Smith, eds.), (Oxford and Portland: Hart Publishing, 2017): 125-39.

Tadros, V (2016) Wrongs and Crimes (Oxford: OUP, 2016).

Valentine, M B (2017) “Constructive 'Consent': A Problematic Fiction” Law and Philosophy 37: 499-521.

Wellman, C H (2017) Rights Forfeiture and Punishment (Oxford: OUP, 2017).

Westen, P K (2004) “Commentary: Some Confusions about Consent in Rape Law" Ohio State Journal of Criminal Law 2: 332-359.

Wilken, S and Ghaly, K (2012) The Law of Waiver, Variation and Estoppel, 3d ed. (Oxford: OUP, 2012).

Zipursky, B C (2014) "Civil Recourse and the Plurality of Wrongs: Why Torts are Different" New Zealand Law Review 2014: 145-169. 